List of Figures vii

List of Tables xiii

Acknowledgments $\quad \mathrm{xv}$

I Lithics in Sedentary Societies: Themes, Methods, and Directions

Rachel A. Horowitz and

Grant S. McCall 3

2 Urban Lithics: The Role of Stone Tools in the Indus Civilization and at Harappa

Mary A. Davis 36

3 The Importance of Being Ad Hoc: Patterns and Implications of Expedient Lithic Production in the Bronze Age in Israel

Francesca Manclossi and

Steven A Rosen $\quad 69$

4 Leaving No Stone Unturned: Expedient Lithic Production among Preclassic Households of San Estevan, Belize, and K'o and Hamontún, Guatemala

Jason S.R. Paling $\quad 89$

5 The Economic Organization of the Extraction and Production of Utilitarian Chert Tools in the Mopan Valley, Belize Rachel A. Horowitz $\quad 139$ 
6 Chert at Chalcatzingo: Implications of Knapping Strategies and Technological Organization for Formative Economics

Grant S. McCall, Rachel A. Horowitz, and Dan M. Healan $\quad{ }^{16} 6$

7 Unraveling Sociopolitical Organization Using Lithic Data: A Case Study from an Agricultural Society in the American Southwest Fumiyasu Arakawa $\quad$ I84

8 Using Portable X-Ray Fluorescence (pXRF) to Source Burlington Chert from the Carson Site, $22 \mathrm{CO}_{5} \mathrm{O}_{5}$, Coahoma County, Mississippi Jayur Madhusudan Mehta, Grant S. McCall, Theodore Marks, and James Enloe $\quad 208$

9 Stone Age Economics: Efficiency, Blades, Specialization, and Obsolescence

John C. Whittaker

229

List of Contributors

Index 249 
Archaeologists studying sedentary, hierarchical societies have offered vivid accounts of many striking forms of material culture: monuments requiring complex engineering and massive investments of labor; crafts requiring enormous skill and specialized networks of production and distribution; prestige goods marking the wealth, status, and power of elites; and other manifestations of social complexity too numerous to list. Similarly, archaeologists studying stone tools have documented an endlessly diverse range of complex core reduction and tool manufacture practices: thinned bifacial projectile points, the Levallois technique, prismatic blade production, obsidian and chert eccentrics, and countless others. In certain instances, stone tool production in sedentary societies itself took the form of a specialized craft-for example, the production of obsidian blades in Mesoamerica or Neolithic daggers in Scandinavia - and it has thus been studied by the nexus of those concerned with both sedentary societies and stone tools. Unfortunately, however, the vast majority of lithic production in sedentary societies (which tended to be informal and expedient) has received very little attention.

This volume presents case studies of lithics in sedentary societies around the world. The chapters generally reflect the traditional directions of lithic studies in sedentary societies and emphasize the important information lithics can provide about anthropological questions of interest to scholars of sedentary societies.

\section{Lithics in Sedentary} Societies

Themes, Methods, and Directions

Rachel A. Horowitz and

Grant S. McCall

DOI: 10.5876/9781607328926.coor 
This chapter reviews some of the general trends in global analyses of lithic technology and draws on the chapters in this volume to discuss directions for future research and the relevance of lithic studies to broader anthropological questions. This chapter is organized around four general themes: (I) what lithics can and cannot tell us about sedentary societies, (2) why we should study informal/expedient lithic technologies, (3) how studies of specialized stone tool production fit into the archaeology of both lithics and sedentary societies, and (4) how we build a better approach to the archaeology of stone tools in contexts in which they have generally been ignored up to this point.

Our answers to these questions point to some broader theoretical issues in terms of our reconstruction and modeling of prehistoric economic systems. On the one hand, we find fault with the overwhelming-sometimes seemingly exclusive-focus on production. Our conceptions of production in sedentary societies have articulated well with the latter-day preference for theories based on agency and practice. Yet as this book will show, there are many instances in which unspecialized forms of economic activity profoundly reflect important dynamics of both everyday life and the broader organization of prehistoric economies. Conversely, when stone tools are the result of craft specialization, there are many aspects of their manufacture that may shed light on prehistoric social and economic systems that go beyond a simple sequence of production, the acquisition of a craftsperson's skill, or the elite control of economic commodities. The chapters in this book shed light on these problems and explore some ways forward.

\section{LITHICS IN SEDENTARY SOCIETIES}

One axiom about the archaeology of stone tools is that as the most durable form of artifact in the archaeological record, lithics virtually last forever. As such, they are often the only remaining manifestation of the activities of our hunter-gatherer ancestors. Thankfully, mobile forager societies often did us the favor of producing handsome and complex lithic technologies, and the field of archaeology has done (relatively) well in relating this inherently unfamiliar form of artifactual patterning with the life ways of long-dead hunter-gatherers, especially in terms of subsistence and mobility. Put simply, hunter-gatherer archaeologists have paid so much attention to stone tools because we have not had many other options.

In contrast, more recent sedentary societies have usually left behind a bewildering diversity of durable garbage, and archaeologists of sedentary societies have therefore tended to focus on more familiar or more striking phenomena 
or both. (Never mind that pile of broken rocks; let's go explore that pyramid.) In addition, relative to other forms of material culture, such as ceramics, lithics aren't even terribly chronologically or culture-historically diagnostic. Thus, for eminently understandable reasons, archaeologists of sedentary societies have tended to prioritize research on monuments, burials, tombs, palaces, jewelry, and ceramics and not studies of lithic technology. Sometimes certain specialized forms of lithic manufacture have been dazzling enough to warrant investigation alongside these other trappings of complexity, though such instances are comparatively rare. Furthermore, the outcomes of such research have tended to be understood with reference to the power of elites, which is, after all, probably reflected better by other forms of material remains, such as those listed above.

Another axiom of lithic analysis is that stone tool technology is reductive; that is, the process of producing and recycling stone tools involves taking large rocks and systematically breaking them to produce smaller rocks. This process of systematically detaching pieces from lithic objects (e.g., reducing cores, thinning bifaces, retouching blanks, and the like) results in an inferable sequence of technical procedures, or a chaîne opératoire, spanning the initial acquisition of lithic raw materials to the ultimate deposition of lithics into the stasis of the archaeological record. In some cases, entire sequences of technical operations took place at a single location, and thus such sites may include evidence concerning the complete life history of the stone tools present at them. In other cases, different stages of the operational sequences involved in stone tool reduction took place at different locations, reflecting mobility or the exchange of lithics as an economic commodity or some combination of the two. Reconstructing the operational sequences involved in stone tool production, as well as the spatial distribution of the various stages of these sequences of reduction, provides an invaluable window on the economic activities and decisions faced by prehistoric peoples involved in the production, exchange, and consumption of lithic technology.

On this point, we come to an important truth about the nature of lithic technology in the lives of past peoples in sedentary or complex societies or both: stone tools were probably not that important relative to other forms of technology and other economic concerns. Disasters happened when crops failed, when water sources dried up, when deadly diseases struck, or when enemy neighbors attacked. In contrast, it was perhaps a modest inconvenience when tool stone became scarce, when working edges became dull, when bifaces broke, or when the blades ran out. Unlike other aspects of economic production, lithic technology was seldom a life-or-death issue for prehistoric peoples 
(excepting perhaps the rare craft specialists whose livelihoods depended on stone tool production).

This does not mean, however, that archaeological stone tools cannot provide profoundly important information about the lives of prehistoric peoples. Stone tools may not have been as important as all of the other economic commodities exchanged through the trade networks linking polities in various complex societies. Yet by virtue of their durability, their reductive transformation from the quarry to point of consumption and discard, and the spatial variation in the diagnostic waste associated with different stages of reduction, stone tools may be crucial sources of information about the organization of exchange networks over space and time. All the perishable goods that flowed through those exchange networks-goods on which people's lives often literally depended-may be long gone, leaving behind little or no trace. But the archaeological record of the stone tools that flowed through those exchange networks remains, layered with sequential information concerning the activities of the people who produced them, exchanged them, used them, and threw them away.

Likewise, for farmers, assuring the availability of appropriate lithic technology was likely a rather ephemeral issue relative to the planting, tending, harvesting, and processing of food crops-economic activities on which the lives of family members directly depended. Sometimes, of course, stone tools were specialized components of composite tools that were fairly important in agricultural activities, such as sickle blades or the tribula of threshing sledges. Such forms of agricultural lithic technology have indeed received significant attention from archaeologists (e.g., Anderson et al. 2004; Kardulias 2008; Whittaker 1996, 2003, 2014a, 2014b, 20I4c; Whittaker et al. 2009, this volume; Yerkes 2000), and rightly so. More often than not, however, stone tools were used to manufacture and maintain the components of other tools and weapons (McCall 2012). And since there is almost always some usable stone around somewhere, assuring the presence of appropriate lithic technology usually boiled down to a set of tactics for minimizing inconvenience in finding stone and reducing cores.

Yet while the vital economic activities of farmers usually left little or no trace in the archaeological record, the stone tools associated with these agricultural economic tasks are permanently present, often in cyclopean quantities. Once again, we can make inferences about the sequences of technical activities involved in the manufacture and use of stone tools in such contexts. These operational sequences were articulated with the broader organization of economic activities in which agricultural peoples were involved, and the 
structure of economic activities within agricultural systems conditioned the activities involved in the production of stone tools. We can learn indispensable things about the organization of agricultural economies by investigating how, when, and where people (I) acquired tool stone, (2) reduced cores and produced tools, (3) used tools in different ways over the course of their use-lives, and (4) discarded spent tools in the context of other refuse. Therefore, while the expedient flaking of some chert core in the residential compound of some ancient Mesoamerican farmstead may not be very interesting in its own right (see $\mathrm{McC}$ all et al., this volume), the articulation of knapping activities over space and time with the life-and-death economic activities of those farmers can provide uniquely important information about the life ways of long-dead peoples. Lithic technology, in a sense, mapped onto the economic activities of agricultural peoples that we would like to know more about.

Finally, there is a third axiom about lithic technology: it is globally and temporally ubiquitous in prehistory. Prior to the spread of metallurgy, stone tools had been produced by virtually every prehistoric society on every inhabited continent, from Plio-Pleistocene australopiths in the Rift Valley of sub-Saharan Africa to the sixteenth-century Aztecs of central Mexico. In fact, many resourceful peoples in complex societies continued to produce stone tools long after the advent of metal counterparts (see Davis, Manclossi and Rosen, and Whittaker, this volume), in part because of the widespread (although uneven) distribution of suitable lithic raw material sources. And a reasonable number of modern peoples continue to produce stone tools today (see McCall 2012 for discussion).

One implication of all this is that the archaeological record of stone tools is immense, diverse, and associated with nearly all past peoples. The other implication is that we can surely profit from studying variability in lithic technology over the vast diversity of contexts in which it may be found. We have accomplished this, at least to some extent, in our examinations of prehistoric hunter-gatherer technological systems, where we have demonstrated that stone tool technologies tend to vary in relation to mobility, settlement systems, and subsistence strategies. Yet our understanding of the lithic technologies of sedentary societies remains relatively poor, and in these cases the conventional hunter-gatherer organizational currencies of mobility/settlement and subsistence do not make sense. Obviously, a better empirical understanding of these cases is needed, as is a better theoretical toolkit for making sense of lithic variability as we continue to document it.

Chapters in this book build on a certain set of theoretical innovations in the study of the lithic technological systems present among sedentary agricultural 
societies. Specifically, the chapters examine the ways lithics may provide information about economic activity, political organization, resource and production management, and the relationship between societal and technological change. Lithics are perhaps most commonly studied in sedentary societies as a way of understanding the segmentation and organization of past economic systems (Druart 20I0; McDonald I99r; Parry and Kelly 1987; Rosen 20I0; Sorensen 20I0; Teltser I99r; Torrence I984, I986; Horowitz, McCall et al., and Paling, this volume). Lithic distribution patterns have sometimes been used as indicators of various types of economic activities, vectors of resource distribution, and the relevant involvement of different individuals in economic activity (i.e., market exchange; Garraty 2009; Hirth 1998, 20I0; Minc 2006, 2009; Santone 1993; Speal 2009; Stark and Garraty 2010).

These sorts of theoretical approaches to the study of lithic technology have been particularly prevalent in the archaeology of Mesoamerica, as exemplified by the three Mesoamerican chapters in the volume (Horowitz, McCall et al., and Paling). All three chapters focus on the importance of formal and informal tools in various aspects of Mesoamerican economies, pointing out in all cases that household residents participated in many aspects of lithic production, particularly of informal tools. These chapters illustrate the variability of lithic production across Mesoamerica, in particular the presence of both formal and informal tool technologies, a phenomenon discussed further below and by Manclossi and Rosen, and McCall et al. (this volume).

Our understanding of prehistoric economic strategies, variability among economic activities, and the actors involved in lithic economies affects our understandings of economic variables as sources of power for individuals of varying socioeconomic and political statuses, hence facilitating information on political organization and sources of power (see Schroeder 2005). In this volume, Arakawa provides an example of such studies from the southwestern United States. He uses lithics as a marker of sociopolitical organization, particularly for examining territoriality and the movement of populations. Similarly, Mehta and colleagues (this volume) address the role of political influence from other areas on the obtention of chert materials in the Lower Mississippi Valley, particularly the Carson site. The use of lithics to address economic and sociopolitical organization enhances our abilities to examine these systems in the past, particularly highlighting the ways different materials may illustrate variability in such systems, or throughout their use-life (see Appadurai 1986).

Another direction in the study of stone tool technology is the organization of resource procurement, particularly in terms of the management of lithic 
raw material sources. Within sedentary societies, extensive variability exists in the ways raw material sources were managed. In many Egyptian, GrecoRoman, and Inka contexts, quarry areas for building materials and tool construction, and the resultant products, were under some degree of imperial control (Cantarutti 2013; Degryse et al. 2009; Harrell and Storemyr 2009; Jennings et al. 2013; Kelany et al. 2009; Lollet et al. 2008; McCallum 2009; Ogburn 20II, 2013; Peacock and Maxfield 2007; Teather 20Ir; Torrence I984; Tripcevich and Contreras 20II, 2013; Weisberber 1983). Evidence for such control takes the form of (I) organized work areas, including storage facilities (Cantarutti 20I3; Harrell and Storemyr 2009; Storemyr et al. 20Io); (2) transportation routes (Harrell and Storemyr 2009; Heldal 2009; Kelany et al. 2009; Ogburn 2013; Storemyr et al. 2010); (3) the scale and organization of production (Heldal 2009; Salazar et al. 2013); (4) widespread distribution of finished products (McCallum 2009); (5) organized villages for workers (Harrell and Storemyr 2009; Peacock and Maxfield 2007); and (6) state-sponsored ritual in and around work areas (Vaughn et al. 2013). Less evidence, however, exists in other areas of the world for such strict top-down management (i.e., Cobb I988, 2000; Horowitz 2015, 2017, 2018; King 2000; Horowitz, this volume). This is an indication that there is variability in the management of lithic resources in sedentary societies and that this variability may shed light on the nature of prehistoric social, economic, and political systems.

The manufacture techniques involved in lithic production are perhaps the most widely studied aspect of stone tool technologies in sedentary societies, as they have often been linked to broader features of economic organization in prehistoric societies (Chinchilla Mazariegos 20II; de Leon 2008; Dolores Soto 2005; Gaxiola Gonzalez 2005; Gaxiola Gonzalez and Guevara I989; Healan 1989, 2002, 2003; Hirth 20II; Kerley 1989; Lewis I995; Parry 2002). Such studies focus on the location of production, continuity/regularity of production, and management of production activities by non-craft producers. The temporality of production (full-time versus part-time specialization, intermittent production, multicrafting) is an arena of great debate among scholars, both in how one determines production amounts and also concerning the importance of such production activities for understanding the involvement of various actors in different aspects of production (see Costin 1991, 1996, 2000, 2004; Costin and Hagstrum 1995; Hirth 2009 for more details). Determining the relationship between craft producers and other individuals can be complicated (see Carballo 2013; Hirth 2009, 20II), although establishing such relationships can provide information about the economic implications of production activities. 
Perhaps one of the most important emerging avenues of discussion/elaboration in studying lithics in sedentary societies involves technological change and what it can tell us about change in other aspects of society. While major social and economic transitions may not always be reflected in lithic technological systems (e.g., McCall and Horowitz 20I4), major periods of technological change can often signal profound shifts in prehistoric socioeconomic systems. As Marx (197I [1859]: ro9) commented in Das Kapital, "The hand-mill gives you society with the feudal lord; the steam-mill society with the industrial capitalist." On the one hand, we doubt that the obsidian prismatic blade gives you Mesoamerican civilization or any other equivalent sentiment for other times and places. On the other hand, we are confident that major changes in prehistoric social, economic, and political systems were indeed reflected in archaeological patterning associated with the production, distribution, and consumption of lithic technological resources.

Chapters in this book address two areas of particular interest to technological change in sedentary societies: the advent of metallurgy and the changes to technology that occur with cultural contact. In many cases, after the introduction of metal, stone tools were no longer utilized. In others, lithic use continued for longer periods of time. In some cases, tools that continued to be produced from stone were those for which the functional characteristics of raw materials were superior to metal or when lithics were used for ritual purposes (Bamforth 1993; Bronowicki and Masojc 20ro; Cobb 2003a, 2003b; Cobb and Pope 1998; Cobb and Ruggiero 2003; Flexner and Morgan 2013; Frieman 2010; Johnson 1997, 2003; Karimali 2010; McCall 2012; Odell 200I, 2003; Raczek 20I0; van Gijn 20I0; Davis, this volume; Manclossi and Rosen, this volume). The longest-lasting of these examples is gunflints, made in Europe and the Americas from the early I500s to the late I80os (Kenmotsu 1990; Kent I983; Watt and Horowitz 20I7; White 1975; Whittaker 20or; Woodall et al. 1997).

Other examples in sedentary societies include blades for sickle production in the Near East (Whittaker 1996, 2003, this volume; Whittaker et al. 2009; Yerkes 2000) and other types of tools in the circum-Mediterranean world (Eriksen 20I0; Kardulias 2008, 2009; Milevski 20I3; Rosen 1996). Blade production for use as parts of sickles and threshing sleds continued after the advent of metal; Canaanean blade technology in the Near East began in the Early Bronze Age (Rosen 1983, 1997), in conjunction with the advent of metallurgy (Anderson et al. 2004; Rosen 1996, 1997; Rosen et al. 2014). In some areas of the Mediterranean, the Balkans, and the Black Sea, the threshing industry, using stone blades, continued as late as the I950s in Cyprus and the I980s in some areas of western Turkey, probably as an extension of the techniques that 
began in the Bronze Age (Anderson et al. 2004; Kardulias 2008; Whittaker 1996, 2003, 20I4a, 20I4b, 20I4c, this volume; Whittaker et al. 2009; Yerkes 2000). The persistence of specialized lithic technology beyond the introduction of metal tools adds complexity to our understanding of how technologies change and what this can tell us about the ways technological change reflects - or does not reflect-broader patterns of sociopolitical organization. In this case, the continuity of some lithic production traditions in conjunction with the production of new tool types of different materials highlights the importance of raw material properties for specific tasks and the continuity of tools that are best for such tasks.

In other cases, lithic technology persisted past the appearance of metal for other economic reasons. Lithics often offer a cheap and effective alternative to metal tools in situations in which the latter may be difficult or expensive to acquire. In this volume, Manclossi and Rosen describe the persistence of expedient lithic technologies into the Near Eastern Bronze Age. In this case, and others like it in the early metal ages, stone tools weren't necessarily more functionally effective than their metal counterparts, but they were much cheaper and ubiquitously available. Resourceful peoples around the world and into the modern day have repeatedly returned to basic practices of stone tool production in situations where metal is hard to find, expensive, or otherwise impractical.

Another widespread example of this phenomenon involves the knapping of new materials, especially bottle glass (Johnson 1997; Raczek 2oro; Shott and Weedman 2007; Weedman 2000, 2002, 2006; see also McCall 2012). Glass knapping is particularly interesting because it often occurs alongside the use of metal tools and as a continuation of older practices of stone knapping. In Ethiopia, modern hideworkers produce and use glass scrapers, which may have functional advantages over putative metal counterparts and which are cheaper than scrapers made on chert or obsidian, since lithic raw material sources are often tightly controlled by local clans and stone is often sold in markets at considerable cost (Weedman 2000, 2002, 2006). Here, glass knapping provides a more effective solution to the technical problems than does metal and is a cheap alternative to knapped stone.

The utilization of knapped glass has also been documented among the Highland and Lacandon Maya (Clark 1989, 199r; Deal and Hayden 1987; Hayden and Deal 1989; Maler 1902; Tozzer 1907; see also Weigand 1989). Under one set of circumstances, expediently knapped glass, which is often salvaged from garbage deposits, provides a cheap and easy solution in the manufacture and maintenance of wood, bone, and leather components of other tools. In other situations, glass has replaced obsidian in the manufacture of tools 
for rituals, such as blood-letting ceremonies. Obsidian is generally hard to come by in the modern Maya world, but glass is not. Thus glass as an obsidian replacement facilitates the continuation of an ancient set of ritual practices using a modern raw material. In general, the production of glass tools informs us about how technological change co-occurs with changing social and political interactions and the impact of colonial contact on material culture (e.g., Chatfield 2013; Harrison-Buck et al. 2013; Tolmie 2013).

While variation among the lithic technologies of sedentary societies is immense, the chapters in this book focus on a central distinction between the production of informal tools, which are often expedient and take the form of utilized flakes produced from locally occurring raw material sources, and the production of formal tools, which are often complex in their design, require considerable skill on the part of the craftspeople who produce them, and are often distributed widely from their sources through extensive networks of exchange. We recognize that this distinction likely retains some of the baggage of the culture-historical focus of the early field of archaeology, as well as the typological tunnel vision of early approaches to lithic analysis. But we have to start somewhere, and learning about the sources of this distinction, as well as the nature of variation within these two categories, can be seen as a first step in using lithic technology to understand the social, economic, and political systems of sedentary agricultural societies.

\section{INFORMAL TOOLS, OR THE COMPLEXITY OF THE INFORMAL}

As Nelson (199I) and Andrefsky (2005) define them, informal tools are unstandardized, require minimal effort in construction, and are produced with immediately available raw materials and with little concern for the final tool form. Formal tools require more effort, planning, and skill in their manufacture and are more costly in terms of production effort and raw material quality, but they hold added value in terms of their design, such as increased versatility, maintainability, or effectiveness relative to some specific function. As an overlapping concept, Binford (1976) defines expediency as the ad hoc production of a tool from immediately available materials for the resolution of some immediate technical problem, followed by the immediate discard of the tool once its use has been completed. Binford contrasts expediency with curation, which refers to the retention of a tool for some period of time in anticipation of a future need.

The field of archaeology has not fully recovered from the confusion surrounding these concepts (e.g., Shott 1996). We stress that expediency and 
curation are not merely contrasting strategic options available to individuals in making decisions about their technology and that informal tools may sometimes be curated and formal tools may sometimes be used expediently. Furthermore, the distinction between informal and formal tools offers a simple vocabulary for talking about the basic formal qualities of stone tools in the archaeological record and the manufacture processes through which they were produced. Expediency and curation are a vocabulary for talking about the technological strategies employed by past peoples, about which we strive to make inferences based on the things we find in the archaeological record.

Some time ago, archaeologists studying sedentary agricultural societies and the lithic technologies they produced had to come to grips with the fact that many - perhaps most - of these lithic technologies are dominated by the production of informal tools, which provides evidence for largely expedient lithic technological systems. Much of our way of thinking about this situation stems from the influential paper by Parry and Kelly (1987), which argues that sedentism results in the stockpiling of lithic raw materials within residential units, meaning that people no longer needed to conserve these materials by producing complex formal tools (e.g., bifaces, blades), as did most mobile hunter-gatherers. Thus sedentary peoples tended to utilize unretouched flakes produced expediently from cores made on raw materials stored at residential units.

Parry and Kelly's (1987) generalization about the lithic technology associated with sedentary societies has been remarkably durable, even in the light of three decades of subsequent research. Likewise, their theoretical explanation of this empirical generalization has remained fairly popular because of its clear intuitive appeal. While the Parry and Kelly paper has propelled the field forward in thinking about the sources of variability in the lithic technologies of prehistoric societies, some cracks in the foundation of this model have become apparent. For one thing, as we discuss in more detail below, there are many cases in which the facts defy the Parry and Kelly generalization (see also Cobb and Webb 1994; Hofman 1987; McNerney 1987). We approach this issue in the next section, which deals with specialized lithic technologies.

For another thing, there are some problems with the Parry and Kelly (1987) theoretical explanation of the prevalence of expedient/informal lithic technologies in sedentary societies. Specifically, in both archaeological and ethnographic cases of stone tool production, the evidence for lithic raw material abundance and stockpiling at residential centers is scarce. In this volume, McCall and colleagues examine a dimension of this problem at the site of Chalcatzingo. Here, prehistoric knappers collected locally available chert and knapped it using informal/expedient knapping strategies—all in keeping with the Parry 
and Kelly model. In contrast, in many cases the Chalcatzingo chert knappers reduced cores to almost ridiculous extremes, including through the use of bipolar percussion. Clearly, knappers at Chalcatzingo were concerned with economizing raw material in the reduction of chert cores. However, they achieved this goal through the exhaustive use of informal strategies of core reduction rather than adoption of more formal methods of core reduction for the purposes of raw material economy, such as bifacial thinning or prismatic blade production. Furthermore, there is no evidence for stockpiling in this case or in many others like it.

Similarly, Manclossi and Rosen (this volume) find continuity in the informal, or ad hoc, lithic industries associated with metal technologies in the Near East, and they attribute more formal lithic technologies to the rise of specialization in lithic production. Increased specialization led to a decrease in lithic production skill by other knappers, hence increasing the importance of these informal but common tools created by individuals as needed. The causes of informal tool technologies illustrate the importance of the detailed examination of those technologies, as such technologies inform us about the organizational dynamics of past societies. Once again, Manclossi and Rosen show that the Parry and Kelly (1987) model only partially tells the story of informal lithic technologies in the later prehistory of the Near East. Studies such as these help demonstrate the vital importance of understanding informal stone tool industries in sedentary societies and of doing so in a way that focuses on the isolation of strategic variability over space and time. Doing so will allow us to get beyond the Parry and Kelly (1987) model—successful though it has been - to build a better framework for making inferences about the economic and social contingencies that shaped the lives of individuals in past sedentary farming societies.

Building an analytical framework for making sense of variability among informal stone tool industries in sedentary societies may also allow us to improve upon a preoccupation with craft production both as the basis of individual economic activity and as the source of identity at its many scales. A great deal of archaeological theory in the twenty-first century, especially that dealing with complex societies, has been based on concepts of agency and practice (Bourdieu 1977; Dobres and Robb 2000; Giddens 1979). For example, in examining the production of obsidian eccentrics at the Classic Maya site of Piedras Negras, Hruby (2007) argues that the highly complex and ritually structured knapping practices involved in producing this extreme form of prestige good were themselves key mechanisms in the embodiment of both individual and collective identity. 
Agency and practice theory puts a premium on the study of craft production involving products with distinctive formal characteristics and complex sequences of production activities, usually those involving great skill on the part of the craftsperson. In lithic technology terms, Hruby's (2007) study of Maya eccentrics fits the bill perfectly. Yet expedient and informal technologies, such as those endemic to large numbers of sedentary societies, hold little appeal for those interested in agency and practice. To put it bluntly, it is hard to argue that a prehistoric farmer who expediently removed a sequence of flakes from some core lying around the farm somehow embodied her identity in doing so when it was the geometry of the core and perhaps the immediate contingencies associated with the need for a sharp flake that shaped the gestures involved in knapping.

In thinking about a modern equivalent, it would be like arguing that one could embody one's identity or individual agency in how one goes about repairing a hole in a screen door with a strip of duct tape. Even if some people derive aspects of their identity from their use of duct tape (many of them archaeologists, no doubt), this is not the principal dynamic reflected in the technical gestures associated with the duct tape repair-and the issue obviously becomes much trickier in the archaeological record, where we have access to evidence about what people did with technology and not how such practices may or may not have fit into their identity. Even if some aspect of expedient flaking was part of the identity of certain past individuals, what we see archaeologically is the immediate technical response to the problems posed by (I) the requirements of the task at hand and (2) the characteristics of the available technological raw materials.

It may simply be the case that some activities are meaningful in terms of agency and practice but that others are not; that there is a French way to make a croissant but not a French way to hammer in a nail. Yet the difficulty that agency and practice theories have in dealing with expedient technologies highlights a potential analytical critique: how do we know when someone in the past did something a particular way in order to manifest some aspect of their identity and not simply because it was the easiest way of responding to the technical contingencies that happened to be facing them at that moment? Answering this question would require us to know something that we, as archaeologists, are fundamentally incapable of knowing: what was on the minds of people in the past. We return to this theme again in the next section, which deals with formal stone tool traditions.

In any case, for now we have established that expedient/informal core reduction does not relate very well to current theoretical foci of agency and 
practice - or, for that matter, to materiality, monumentality, temporality, memory, and so on. So why should we bother studying this phenomenon at all? As we stated earlier, while the gestures involved in expedient core reduction themselves are not that interesting, they are carried out and distributed over space and time in ways that reflect economic activities that are of utmost interest. As the chapters in this volume will demonstrate, there are many ways in which the various stages of the expedient core reduction process are integrated within the broader economic activities of prehistoric farmers. Here are a few points of particular interest discussed in this book:

I. The integration of lithic raw material collection into other economic activities, such as the tending of farm fields, the extraction of other kinds of raw material resources from the landscape, and interaction/exchange with other populations and settlements

2. The technological goals reflected in the specific strategies of expedient core reduction, the production of utilizable flakes, and the selection of particular flakes for use in performing certain tasks

3. The raw material economic decisions reflected by the use of certain core reduction strategies, the length of core reduction sequences, and the degrees of core exhaustion

4. The technical contingencies reflected by the recycling and repurposing of utilized flakes through different retouch tactics

5. The location and timing of knapping activities as reflected by the context of discarded lithic materials and the other artifacts and features with which they are associated.

Naturally, this is only the beginning of a list of things we should study about the informal stone tool traditions of sedentary societies, but it is a place to start. More generally, we need to develop a better analytical framework for relating the characteristics of informal lithic industries in sedentary societies with the salient economic dynamics they are capable of reflecting. This is no easy task, and it will require profound creativity when it comes to thinking through how lithic manufacture as a spatially and temporally distributed reductive process related to other economic activities in ways that are archaeologically visible. We hope this volume makes a contribution in this pursuit, if for no other reason because it demonstrates that the Parry and Kelly (1987) model does not explain it all and that studying informal lithic traditions in sedentary societies has a legitimate place in the field of archaeology alongside studies of other, more complex forms of craft production. 


\section{SPECIALIZED TOOL FORMS}

Specialized tools have formed the core (if you will excuse the pun) of lithic studies in sedentary societies, and for good reason. For one thing, specialized tool forms tend to be more culture-historically diagnostic and significant, at least in contrast to expedient flake production, which tends to be ubiquitously lacking in typologically distinctive formal features. In addition, specialized tool forms relate more clearly to political-economic issues that are of theoretical interest to archaeologists, such as craft specialization, trade, elite control of economic resources, sociopolitical inequality, and similar factors.

Two prime examples of specialized tool production, resulting from formal core technology, are obsidian prismatic blades found throughout Mesoamerica and sickle blades in the Near East and elsewhere in the Old World. These specialized implements are functionally distinct from informal lithic technologies, which were often used alongside them contemporaneously. In addition, specialized tools were produced and distributed in unique ways, often involving both the restricted control of lithic raw material sources and the production activities of highly skilled and specialized craftspeople. In places like Mesoamerica and the Near East, the production of these specialized tool forms articulates with the operation of broader economic systems in important and illustrative ways. It is no wonder that they have garnered so much previous attention.

Mesoamerican obsidian prismatic blade production in particular has been discussed at great length elsewhere (see Gaxiola Gonzalez and Clark 1989; Hester 1978; Hirth 2003, 2006; Hirth and Andrews 2002; Levine and Carballo 2014 for summaries of this research). The production of such materials involves preparation and production of highly structured formal cores, which were then distributed outside the areas of raw material accessibility (a relatively restricted volcanic area of highland Guatemala and Mexico). Prismatic blades were produced by craft specialists and distributed through a variety of mechanisms, including elite management and itinerant craftspeople. The study of obsidian prismatic blade production has shed light on the political-economic systems of prehistoric societies from nearly every region and time period of Mesoamerica, from the Formative villages of the Olmecs to the Spanish contact-period cities of the Aztecs.

Morphologically similar tools were used for agricultural activities in the Near East; sickles produced on blades became more formal over time, with early examples in the Late Natufian period (I2,800-I0,200 BP; Belfer-Cohen and Goring-Morris 1996) giving rise to the highly formalized Naviform blade core technology in the Pre-Pottery Neolithic B (PPNB; 9500-7900 
BP; Bar-Yosef et al. 1991; Goodale et al. 2002, 2010; Nishiaki 2000) and continuing into the Bronze Age (see Davis, this volume). Naviform blade cores are boat-shaped and standardized in shape and size, use percussion technology for blade production (Quintero and Wilke 1995), and are generally produced on high-quality, exotic raw materials (Quintero 1996). By the Pottery Neolithic (PN; 7500-6000 BP), the formality of cores decreased, with an emphasis on the production of similar tools through blank retouch as opposed to similarities in the blanks themselves (Finlayson et al. 2003; Gopher et al. 200I). This blade technology exists through the introduction of metal tools, referred to by this time as Canaanean blades, which are extremely standardized (Anderson and Chabot 2001; Anderson et al. 2004; Milveski 2013; Rosen 1996, 1997), although those found at Harrapa are less standardized (Davis, this volume).

In both Mesoamerica and the Near East, the formality of cores contrasts with Parry and Kelly's (1987) expectations for the informality of core technology in sedentary societies. In both cases, blades were used for composite technologies (Anderson and Chabot 200r; Bleed 1986; Nelson 1991; Shott 1989). Ethnographic studies illustrate that haft construction is frequently the most expensive part of component tools (Gould I980; Rule and Evans 1985; Weedman 2002, 2006), which explains the preference for replacing the components rather than the haft. In both Mesoamerica and the Near East, blades are preferentially produced on high-quality raw materials, mostly non-local, which results in specialized production areas close to sources and intensive utilization of cores and tools outside source areas (Anderson et al. 2004; Davis, this volume; Quintero and Wilke 1995; Rosen 2013; Willke 1996; Wilke and Quintero 1994).

The production and exchange of these specialized tool forms in sedentary societies was predicated on the exchange systems and craft specialization present in these societies. We might ask, for example, why are there cases such as the production of obsidian blades in Mesoamerica and sickle blades in the Near East that so thoroughly defy the Parry and Kelly (1987) generalization about lithics in sedentary societies? We would argue that the presence of extensive networks of exchange was, in a sense, the tail that wagged the dog of specialized stone tool production. Such exchange networks arose in the context of the distribution of a wide range of consumable goods and durable craft products. Once in place, these exchange networks created economic opportunities for those who controlled major sources of high-quality lithic raw materials and the craftspeople who were involved in specialized stone tool production at workshops located near these sources. Without 
suitable networks of exchange, the exploitation of such high-quality lithic raw material sources would have remained a local phenomenon, and the Parry and Kelly (1987) pattern of expedient knapping would most likely have been borne out.

For example, in this volume McCall and coauthors document the expedient knapping of chert at Chalcatzingo, which occurred alongside the highly specialized production of obsidian prismatic blades in elite-controlled craft workshops (see also Grove 20I4). Were it not for the presence of the exchange networks through which the many goods from Chalcatzingo flowed into the Olmec world, there would have been no demand for obsidian prismatic blades, no need for control/exploitation of the obsidian quarries in the region, and no need for specialized workshops to produce blades. Thus the prevalent pattern of expedient chert core reduction would have been the norm, obsidian would have been rare, and blade production (for the most part) would not have occurred.

It is also the case that the limited locations of specialized stone tool production identified archaeologically in sedentary societies indicate that relatively few producers were responsible for the production of prepared cores. Most sites with Canaanean blades show no evidence of local production, indicating that the finished products arrived from elsewhere through trade (Anderson and Chabot 200I; Milevski 20I3; Rosen 20I3). This is also true throughout much of the Maya lowlands, which received blades through trade with settlements in the volcanic highlands that had access to obsidian sources. In addition, at both Near Eastern sites with Canaanean blades and lowland Maya sites with obsidian prismatic blades, there is also a great deal of expedient/informal stone tool production using locally available lithic raw materials. Thus the production of these formalized tools co-occurs with a more informal lithic tool technology, produced locally or, in the Canaanean case, with bronze tools.

The organizational properties of lithic technologies in sedentary societies permit the coexistence of informal stone tools, which were produced expediently using local raw materials, and formal technologies, which rely on specialized producers and long-distance trade. While this phenomenon has been noted previously, it has generally been treated as little more than a curiosity. The contrasting dynamics suggested by the coexistence of specialized and informal stone tools, however, have profound implications for our understanding of prehistoric economic systems, as well as clear directions for future research.

First, we suggest that the production of specialized stone tools is most interesting when viewed through the lens of what it can tell us about the economic 
networks and systems that fostered their production. At every stage in the process of specialized stone tool production-from raw material acquisition to the core reduction activities of specialist knappers to the transmission of finished products to the recycling and discard of these products at the location of their consumption-the effects of the political-economic systems and exchange networks in which the various actors were involved can be detected in the technological decisions that were made. Therefore, we would argue that there is great value in studying the organization of specialized stone tool production in relation to the political, in studying the economic systems that brought specialized stone tool production activities into existence.

Second, we feel there are problems associated with the use of agency and practice theory frameworks in examining specialized stone tool production. On a philosophical level, we might ask if prehistoric craftspeople made specialized stone tool products using such systematically consistent techniques because (I) they were ideologically committed, constrained, or both by social, political, or ritual norms and institutions; (2) they manifested some aspect of their identity by doing things that way; or (3) it was the most economically efficient set of methods given the generally invariant conditions of production faced by craftspeople in workshops. It could be none of the above, all of the above, or some combination - but more critically, how would we know?

The interchangeable and simultaneous use of specialized and informal stone tool products also points out the complexity in approaching the ideational underpinnings of any particular pattern of technological behavior. Can practice be an appropriate way of looking at specialized stone tool production when informal/expedient lithic technological systems, which are much harder to deal with using this framework, operated concurrently and co-locationally? If so, why are we so sure of the social significance of one form of technological activity but not the other? And finally, given the primacy of economic networks of exchange in structuring patterns of specialized stone tool manufacture, it is worth questioning how much agency individuals actually had in the face of the necessity for efficiency fostered by commodification of specialized lithic products in the context of trade.

In general, we would argue that examining lithic production without relating it to the specific economic and social conditions under which it occurred leads to the construction of speculative scenarios about knapping behavior in prehistory. When viewed in context as technical responses to the constellation of opportunities and constraints imposed by the operation of economic systems, however we choose to view those, lithic production can provide key clues about the nature of exchange networks, the control of economic 
commodities, and political systems that guided the activities of extractors, craft producers, traders, and consumers. When viewed in isolation, archaeological accounts of lithic production often lead to bald speculation about why knappers did things in certain ways and what knapping activities meant to prehistoric peoples. Once again, as purely ideational phenomena, such quests for motivation and meaning are doomed to ambiguity and conjecture about the past.

\section{GAPS AND FUTURE DIRECTIONS}

Unfathomable volumes of knapping debris are associated with the archaeological records of sedentary societies, and we now know a good deal about the basic characteristics of many of these lithic industries. Yet with the exception of a few famous studies mostly having to do with the role of specialized stone tool production in certain sedentary societies, research on lithics in sedentary societies has unfortunately yielded sadly little concrete information about human prehistory and our theoretical explanation of it. There are still large gaps in our understanding of the importance of lithics, particularly some of the subtitles inherent in the ways they were produced, exchanged, and consumed.

This book illustrates some of the lacunae in our knowledge of lithics in sedentary societies, as well as some analytical, theoretical, and culture-historical points of emphasis that may be useful in resolving them. In terms of analytical methods, one lesson from the chapters in this volume concerns the value of studying whole lithic assemblages rather than focusing on specific tool types or specialized production contexts in isolation. Although the specialized tool types, such as those discussed above, are important in understanding past societies, recognizing variability in lithic production both within and between contexts has much to tell us about the role of lithics in the past. Part of this approach involves the recognition that neither specialized nor informal stone tool production was a monolithic or an invariant phenomenon. Both forms of stone tool production varied over time within particular contexts and (more obviously) between different contexts. The formation of systematic comparisons between the stone tool assemblages associated with different units of the space-time systematics we study as archaeologists is poised to provide novel insights about prehistory. In addition, an examination of the many cases in which specialized and informal stone tool production coexisted contemporaneously may speak to the nature of the broader economic systems in which stone tool production occurred. 
Detailed analyses of assemblage-level data, as proposed by $\mathrm{McC}$ all and coauthors in this volume, provides additional information about reduction processes and the ways those processes interacted with broader social and political systems in ways invisible when only parts of assemblages are addressed. Manclossi and Rosen, in this volume, use detailed core analyses to address differences in informal core and tool technologies, a method that has potential for widespread application in other regions. Other chapters in this volume focus on workshop-level lithic production (Whittaker; Davis) or household-level production (Arakawa; Horowitz; Manclossi and Rosen; McCall et al.; Mehta et al.; Paling). The combination of these types of analyses-that is, comparisons of both formal and informal technology and production areas-provides a more holistic understanding of the production types and techniques employed within sedentary societies.

Other gaps that exist in our studies of lithic technology of sedentary societies are geographic and culture-historical in nature. Although our volume focuses on global perspectives on lithic technologies, some world areas are much more heavily represented than others. This is at least in part a result of the absence of scholars studying lithics in certain world regions. Chapters in this volume examine cases in West Asia, North America, and Mesoamerica. Most striking perhaps is the relative dearth of lithic analysis in much of South America in sedentary societies. Although the study of hunter-gatherers in the region is quite robust, lithics in later societies have received scant attention.

Colloquially, many scholars (including both lithicists focusing on mobile societies and non-lithicist scholars of complex societies) discount the significance of lithics in places like South America and Mesoamerica as "poor quality" or "uninteresting," mostly because of the high frequency of informal tools. As the chapters in this volume show, the very informality of certain lithic assemblages itself and its contrast with specialized forms of stone tool production provide wide ranges of important information on past organizational dynamics. Such preconceptions about informal lithic industries in sedentary societies limit the ways in which both lithic production and economic organization are studied.

We hope this book, if nothing else, makes the case for the value of studying the various lithic industries to be found in the archaeological record of sedentary societies-regardless of whether you agree with our analytical and theoretical perspectives on them. While we have made a good start by addressing a variety of broad anthropological themes from lithic technology around the globe, much more work remains to be done to increase our understanding of the ways studies of lithics can complicate our understandings of the archaeological record and the organization of past societies. 


\section{REFERENCES}

Anderson, Patricia C., and Jacques Chabot. 200I. "Functional Analysis of Glossed Blades from Northern Mesopotamia in the Early Bronze Age (3000-2500 BC): The Case of Tell 'Atij." Série archéométrie r: 257-276.

Anderson, Patricia C., Jacques Chabot, and Annelou van Gijn. 2004. "The Functional Riddle of 'Glossy' Canaanean Blades and the Near Eastern Threshing Sledge.” Journal of Mediterranean Archaeology I7 (I): 87-I30.

Andrefsky, William, Jr. 2005. Lithics: Macroscopic Approaches to Analysis. 2nd ed. Cambridge: Cambridge University Press.

Appadurai, Arjun. 1986. "Introduction: Commodities and the Politics of Value." In The Social Life of Things: Commodities in Cultural Perspectives, ed. Arjun Appadurai, 3-63. Cambridge: Cambridge University Press.

Bamforth, Douglas B. I993. "Stone Tools, Steel Tools: Contact Period Household Technology at Helo." In Ethnohistory and Archaeology: Approaches to Postcontact Change in the Americas, ed. J. Daniel Rogers and Samuel M. Wilson, 49-72. New York: Springer.

Bar-Yosef, Ofer, Avi Gopher, Eitan Tchernov, and Mordechai E. Kislev. I99r. "Netiv Hagdud: An Early Neolithic Village Site in the Jordan Valley." Journal of Field Archaeology I8 (4): 405-424.

Belfer-Cohen, Anna, and Nigel Goring-Morris. 1996. "The Late Epipaleolithic as the Precursor of the Neolithic: The Lithic Evidence." In Neolithic Chipped Stone Industries of the Fertile Crescent, and Their Contemporaries in Adjacent Regions: Proceedings of the Second Workshop on PPN Chipped Lithic Industries, ed. Stefan Karol Kozlowski and Hans Georg K. Gebel, 217-225. Studies in Early Near Eastern Production, Subsistence, and Environment 3. Berlin: Ex Oriente.

Binford, Lewis R. 1976. "Forty-Seven Trips: A Case Study in the Character of Some Formation Processes." In Contributions to Anthropology, the Interior Peoples of Northern Alaska, ed. Edwin S. Hall Jr., 299-351. Ottawa: National Museum of Canada.

Bleed, Peter. I986. "The Optimal Design of Hunting Weapons: Maintainability or Reliability." American Antiquity 51: 737-747.

Bourdieu, Pierre. 1977. Outline of a Theory of Practice. Cambridge: Cambridge University Press.

Bronowicki, Jaroslaw, and Miroslaw Masojc. 20ıo. "Lusatian Flint Industries in Silesia, Southwest Poland." In Lithic Technology in Metal Using Societies-Proceedings of a UISPP Workshop, Lisbon, September 2006, ed. Bert Valentin Eriksen, I07-I27. Hojbjerg, Denmark: Jutland Archaeological Society.

Cantarutti, Gabriel E. 2013. "Mining under Inca Rule in North Central Chile: The Los Infieles Mining Complex." In Mining and Quarrying in the Ancient Andes: 
Sociopolitical, Economic, and Symbolic Dimensions, ed. Nicholas Tripcevich and Kevin J. Vaughn, I85-2II. New York: Springer.

Carballo, David M. 2013. "The Social Organization of Craft Production and Interregional Exchange at Teotihuacan." In Merchants, Markets, and Exchange in the PreColumbian World, ed. Kenneth G. Hirth and Joanne Pillsbury, II3-I4O. Washington, DC: Dumbarton Oaks Research Library and Collection.

Card, Jeb J. 20I3a. "Introduction." In The Archaeology of Hybrid Material Culture, ed. Jeb J. Card, I-2I. Center for Archaeological Investigation, Occasional Paper 39. Carbondale: Southern Illinois University.

Card, Jeb J. 2013b. "Italianate Pipil Potters: Mesoamerican Transformation of Renaissance Material Culture in Early Spanish Colonial E1 Salvador.” In The Archaeology of Hybrid Material Culture, ed. Jeb J. Card, Ioo-I3o. Center for Archaeological Investigation, Occasional Paper 39. Carbondale: Southern Illinois University.

Chatfield, Melissa. 2013. "Worshipping with Hybrid Objects: Assessing Culture Contact through Use and Context." In The Archaeology of Hybrid Material Culture, ed. Jeb J. Card, I3I-I6r. Center for Archaeological Investigation, Occasional Paper 39. Carbondale: Southern Illinois University.

Chinchilla Mazariegos, Oswaldo. 2orr. "The Obsidian Workshop of El Baul Cotzumalhuapu." In The Technology of Maya Civilization: Political Economy and Beyond in Lithic Studies, ed. Zachary X. Hruby, Geoffrey E. Braswell, and Oswaldo Chinchilla Mazariegos, IO2-II8. Sheffield, UK: Equinox.

Clark, John E. 1989. "La tecnica de talla de los lacandones de Chiapas." In La obsidiana en Mesoamerica, ed. Margarita Gaxiola Gonzalez and John E. Clark, 443-448. Mexico City: Instituto Nacional de Antropología e Historia.

Clark, John E. I99I. "Flintknapping and Debitage Disposal among the Lacandon Maya of Chiapas." In The Ethnoarchaeology of Refuse Disposal, ed. Edward Staski and Livingston D. Sutro, 63-88. Phoenix: Arizona University Press.

Cobb, Charles. 1988. "Mill Creek Chert Biface Production: Mississippian Political Economy in Illinois." PhD dissertation, Southern Illinois University, Carbondale.

Cobb, Charles. 200o. From Quarry to Cornfield: The Political Economy of Mississippian Hoe Production. Tuscaloosa: University of Alabama Press.

Cobb, Charles. 2003a. "Introduction: Framing Stone Tool Traditions after Contact." In Stone Tool Traditions in the Contact Era, ed. Charles Cobb, I-I2. Tuscaloosa: University of Alabama Press.

Cobb, Charles, ed. 2003b. Stone Tool Traditions in the Contact Era. Tuscaloosa: University of Alabama Press.

Cobb, Charles, and Melody Pope. r998. "Sixteenth Century Flintknapping Kits from the King Site, Georgia.” Journal of Field Archaeology 25: I-18. 
Cobb, Charles, and Dino A. Ruggiero. 2003. "Lithic Technology and the Spanish Entrada at the King Site in Northwest Georgia." In Stone Tool Traditions in the Contact Era, ed. Charles Cobb, I3-28. Tuscaloosa: University of Alabama Press.

Cobb, Charles, and Paul A. Webb. 1994. "A Source Area Perspective on Expedient and Formal Core Technologies." North American Archaeology I5 (3): 197-219.

Costin, Cathy L. I99I. "Craft Specialization: Issues in Defining, Documenting, and Explaining the Organization of Production." Archaeological Method and Theory 3: I-56.

Costin, Cathy L. 1996. "Craft Production and Mobilization Strategies in the Inka Empire." In Craft Specialization and Social Evolution: In Memory of V. Gordon Childe, ed. Bernard Wailes, 2II-225. University Museum of Archaeology and Anthropology, Monograph 93. Philadelphia: University of Pennsylvania.

Costin, Cathy L. 2000. "The Use of Ethnoarchaeology for the Archaeological Study of Ceramic Production." Journal of Archaeological Method and Theory 7 (4): 377-403.

Costin, Cathy L. 2004. "Craft Economies of Ancient Andean States.” In Archaeological Perspectives on Political Economy, ed. Gary M. Feinman and Linda M. Nichols, I89-22I. Salt Lake City: University of Utah Press.

Costin, Cathy L., and Melissa B. Hagstrum. I995. "Standardization, Labor Investment, Skill, and the Organization of Ceramic Production in Late Prehispanic Highland Peru." American Antiquity 60 (4): 619-639.

De Leon, Jason P. 2008. "The Lithic Industries of San Lorenzo Tenochtitlan: An Economic and Technological Study of Olmec Obsidian.” PhD dissertation, Pennsylvania State University, State College.

Deal, Michael, and Brian Hayden. 1987. "The Persistence of Pre-Columbian Lithic Technology in the Form of Glassworking." In Lithic Studies among the Contemporary Highland Maya, ed. Brian Hayden, 235-33r. Tucson: University of Arizona Press.

Degryse, Patrick, Ebru Torun, Markku Corremans, Tom Heldal, Elizabeth G. Bloxam, and Marc Waelkens. 2009. "Preservation and Promotion of the Sagalassos Quarry and Town Landscape, Turkey.” In Quarry Scapes: Ancient Stone Quarry Landscapes in the Eastern Mediterranean, ed. Nizar Abu-Jaber, Elizabeth G. Bloxam, Patrick Degryse, and Tom Heldal, 99-ro4. Geological Survey of Norway Special Publication I2. Trondheim, Norway: Geological Survey of Norway.

Dobres, Marcia-Ann, and John E. Robb, eds. 2000. Agency in Archaeology. New York: Routledge.

Dolores Soto de Arechalaleta, Dolores. 2005. "Teuchitlan: Un sitio con especializacion en el trabajo: La manufactura de herramientas de obsidiana." In Reflexciones sobre la industria lítica, ed. Leticia Gonzalez Arratia and Lorena Mirambell, I35-I80. Mexico City: Instituto Nacional de Antropología e Historia Colección Científica. 
Druart, Chloe. 2oro. "Production and Function of Stone Arrowheads in the Mycenean Civilization: A Technomorphological and Functional Approach.” In Lithic Technology in Metal Using Societies - Proceedings of a UISPP Workshop, Lisbon, September 2006, ed. Bert Valentin Eriksen, I43-I55. Hojbjerg, Denmark: Jutland Archaeological Society.

Eriksen, Berit. 20Io. "Flint Working in the Danish Bronze Age: The Decline and Fall of a Master Craft." In Lithic Technology in Metal Using Societies-Proceedings of a UISPP Workshop, Lisbon, September 2006, ed. Bert Valentin Eriksen, 8I-93. Hojbjerg, Denmark: Jutland Archaeological Society.

Finlayson, Bill, Ian Kuijt, Trina Arpin, Meredith Chesson, Samantha Dennis, Nathan Goodale, Seiji Kadowaki, Lisa Maher, Sam Smith, Mark Schurr, and J. McKay. 2003. "Dhra' Excavation Report, 2002 Interim Report." Levant 35: I-38. Flexner, James L., and Colleen L. Morgan. 20I3. "The Industrious Exiles: An Analysis of Flaked Glass Tools from the Leprosarium at Kalawao Molokaii." In The Archaeology of Hybrid Material Culture, ed. Jeb J. Card, 295-317. Center for Archaeological Investigation, Occasional Paper 39. Carbondale: Southern Illinois University.

Frieman, Catherine. 20I0. "Imitation, Identity, and Communication: The Presence and Problems of Skeumorphs in the Metal Ages." In Lithic Technology in Metal Using Societies-Proceedings of a UISPP Workshop, Lisbon, September 2006, ed. Bert Valentin Eriksen, 33-44. Hojbjerg, Denmark: Jutland Archaeological Society.

Garraty, Christopher P. 2009. "Evaluating the Distributional Approach to Inferring Marketplace Exchange: A Test Case from the Mexican Gulf Lowlands." Latin American Antiquity 20 (I): $157-\mathrm{I} 74$.

Gaxiola Gonzalez, Margarita. 2005. "Rancho la Canada: Una unidad de producción de instrumentos de obsidiana en Huapalcalco, Hidalgo." In Reflexciones sobre la industria lítica, ed. Leticia Gonzalez Arratia and Lorena Mirambell, I8I-203. Mexico City: Instituto Nacional de Antropología e Historia Colección científica.

Gaxiola Gonzalez, Margarita, and John E. Clark, eds. 1989. La obsidiana en Mesoamérica. Mexico City: Instituto Nacional de Antropología e Historia.

Gaxiola Gonzalez, Margarita, and Jorge Guevara. 1989. "Un conjunto habitacional en Huapalcalco, Hidalgo, especializado en la talla de obsidiana.” In La obsidiana en Mesoamérica, ed. Margarita Gaxiola Gonzalez and John E. Clark, 227-242. Mexico City: Instituto Nacional de Antropología e Historia.

Giddens, Anthony. 1979. Central Problems in Social Theory: Action, Structure, and Contradictions in Social Analysis. Berkeley: University of California Press.

Goodale, Nathan, Ian Kuijt, and Bill Finlayson. 2002. "Results from the 200I Excavations at Dhra', Jordan: Chipped Stone Technology, Typology, and Intraassemblage Variability." Paleorient 28 (I): I25-I40. 
Goodale, Nathan, Heather Otis, William Andrefsky Jr., Ian Kuijt, Bill Finlayson, and Ken Bart. 20Io. "Sickle Blade Life-History and the Transition to Agriculture: An Early Neolithic Case Study from Southwest Asia." Journal of Archaeological Science 37 (6): II92-I2OI.

Gopher, Avi, Ran Barkai, and Amnon Asaf. 20or. "Trends in Sickle Blades Production in the Neolithic of the Hula Valley, Israel." In Beyond Tools: Redefining the PPN Lithic Assemblages of the Levant. Proceedings of the Third Workshop of PPN Chipped Lithic Industry, ed. Isabella Caneva, Cristina Lemorini, Daniela Zampetti, and Paola Biagi, 4II-425. Berlin: Ex Oriente.

Gould, Richard A. 1980. Living Archaeology. Cambridge: Cambridge University Press. Grove, David C. 20I4. Discovering the Olmecs: An Unconventional History. Austin: University of Texas Press.

Harrell, James A., and Per Storemyr. 20o9. "Ancient Egyptian Quarries: An Illustrated Overview." In Quarry Scapes: Ancient Stone Quarry Landscapes in the Eastern Mediterranean, ed. Nizar Abu-Jaber, Elizabeth G. Bloxam, Patrick Degryse, and Tom Heldal, 7-50. Geological Survey of Norway Special Publication 12. Trondheim, Norway: Geological Survey of Norway.

Harrison-Buck, Eleanor, Ellen Spensley Moriarty, and Patricia A. McAnany. 2013. "Classic Maya Ceramic Hybridity in the Sibun Valley of Belize." In The Archaeology of Hybrid Material Culture, ed. Jeb J. Card, I85-206. Center for Archaeological Investigation, Occasional Paper 39. Carbondale: Southern Illinois University.

Hayden, Brian, and Michael Deal. I989. "Vitreous Material Used by the Contemporary Maya." In La obsidiana en Mesoamerica, ed. Margarita Gaxiola Gonzalez and John E. Clark, 435-44r. Mexico City: Instituto nacional de antropolología e historia.

Healan, Dan M. 1989. "Informe Preliminar de las excavaciones en la zona de talleres de Tula, Hidalgo.” In La obsidiana en Mesoamerica, ed. Margarita Gaxiola Gonzalez and John E. Clark, 219-225. Mexico City: Instituto Nacional deAntropología e Historia.

Healan, Dan M. 2002. "Producer versus Consumer: Prismatic Core-Blade Technology at Epiclassic/Early Postclassic Tula and Ucareo." In Pathways to Prismatic Blades: A Study in Mesoamerican Obsidian Core-Blade Technology, ed. Kenneth G. Hirth and Bradford Andrews, 27-35. Los Angeles: Cotsen Institute of Archaeology, University of California.

Healan, Dan M. 2003. "From the Quarry Pit to the Trash Pit: Comparative CoreBlade Technology at Tula, Hidalgo, and the Ucareo Obsidian Source Region." In Mesoamerican Lithic Technology: Experimentation and Interpretation, ed. Kenneth G. Hirth, I53-I69. Salt Lake City: University of Utah Press.

Heldal, Tom. 2009. "Constructing a Quarry Landscape from Empirical Data: General Perspectives and a Case Study at the Aswan West Bank, Egypt." In Quarry 
Scapes: Ancient Stone Quarry Landscapes in the Eastern Mediterranean, ed. Nizar Abu-Jaber, Elizabeth G. Bloxam, Patrick Degryse, and Tom Heldal, I25-I53. Geological Survey of Norway Special Publication I2. Trondheim, Norway: Geological Survey of Norway.

Hester, Thomas R., ed. 1978. Archaeological Studies of Mesoamerican Obsidian. Socorro, New Mexico: Ballena.

Hirth, Kenneth G. 1998. "The Distributional Approach: A New Way to Identify Marketplace Exchange in the Archaeological Record.” Current Antbropology 39 (4): $45^{\mathrm{I}}-476$.

Hirth, Kenneth G. 2003. Mesoamerican Lithic Technology: Experimentation and Interpretation. Salt Lake City: University of Utah Press.

Hirth, Kenneth G., ed. 2006. Obsidian Craft Production in Ancient Central Mexico. Salt Lake City: University of Utah Press

Hirth, Kenneth G. 2009. "Craft Production, Household Diversification, and Domestic Economy in Prehispanic Mesoamerica." Archaeological Papers of the American Anthropological Association I9 (I): I3-32.

Hirth, Kenneth G. 2oro. "Finding the Mark in the Marketplace: The Organization, Development, and Archaeological Identification of Market Systems." In Archaeological Approaches to Market Exchange in Ancient Societies, ed. Christopher P. Garraty and Barbara L. Stark, 227-247. Boulder: University Press of Colorado.

Hirth, Kenneth G. 20Ir. "The Organization of Domestic Obsidian Craft Production." In Producción artesanal y especializacion en Mesoamerica: Áreas de actividad y procesos productivos, ed. Linda R. Manzanilla and Kenneth G. Hirth, I77-203. Mexico City: Instituto Nacional de Antropología e Historia.

Hirth, Kenneth G., and Bradford Andrews, eds. 2002. Pathways to Prismatic Blades: A Study in Mesoamerican Obsidian Core Blade Technology. Los Angeles: Cotsen Institute of Archaeology, University of California.

Hofman, Jack L. 1987. "Hopewell Blades from Twenhafel: Distinguishing Local and Foreign Core Technology." In The Organization of Core Technology, ed. Jay K. Johnson and Carol A. Morrow, 87-Iı. Boulder: Westview.

Horowitz, Rachel A. 2015. "Production at the Source: Lithic Extraction and Production at Callar Creek Quarry, Belize." In Research Reports in Belizean Archaeology: Papers of the 2014 Belize Archaeology Symposium, vol. r2, ed. John Morris, Melissa Badillo, Sylvia Batty, and George Thompson, 45-54. Belmopan, Belize: Institute of Archaeology.

Horowitz, Rachel A. 2017. "Understanding Ancient Maya Economic Variability: Lithic Technological Organization in the Mopan Valley, Belize.” PhD dissertation, Tulane University, New Orleans, LA. 
Horowitz, Rachel A. 2018. "Uneven Lithic Landscapes: Raw Material Procurement and Economic Organization among the Late/Terminal Classic Maya in Western Belize." Journal of Archaeological Sciences: Reports 19: 949-957.

Hruby, Zachary X. 2007 "Ritualized Chipped-Stone Production at Piedras Negras, Guatemala." Archaeological Papers of the American Anthropological Association I7 (I): $68-87$.

Jennings, Justin, Felix Palacios, Nicholas Tripcevich, and Willy Yepez Alvarez. 20I3. "The Huarhua Rock Salt Mine: Archaeological Implications of Modern Extraction Practices." In Mining and Quarrying in the Ancient Andes: Sociopolitical, Economic, and Symbolic Dimensions, ed. Nicholas Tripcevich and Kevin J. Vaughn, I23-136. New York: Springer.

Johnson, Jay K. 1997. "Stone Tools, Politics, and the Eighteenth Century Chickasaw in Northeast Mississippi." American Antiquity 62: 223-235.

Johnson, Jay K. 2003. “Chickasaw Lithic Technology: A Reassessment.” In Stone Tool Traditions in the Contact Era, ed. Charles Cobb, 51-58. Tuscaloosa: University of Alabama Press.

Kardulias, P. Nick. 2008. "Interpreting the Past through the Present: The Ethnographic, Ethnoarchaeological, and Experimental Study of Agriculture.” In Archaeology and History in Roman, Medieval, and Post-Medieval Greece: Studies on Method and Meaning in Honor of Timothy E. Gregory, ed. William R. Caraher and R. Scott Moore, ro9-I26. London: Ashgate.

Kardulias, P. Nick. 2009. "Flaked Stone from Isthmia." Hesperia: The Journal of the American School of Classical Studies at Athens 78 (3): 307-346.

Karimali, Evangelia. 2010. "Lithic and Metal Tools in the Bronze Age Aegean: A Parallel Relationship." In Lithic Technology in Metal Using Societies-Proceedings of a UISPP Workshop, Lisbon, September 2006, ed. Bert Valentin Eriksen, 157-I67. Hojbjerg, Denmark: Jutland Archaeological Society.

Kelany, Adel, Mohamed Negem, Adel Tohami, and Tom Heldal. 20o9. "Granite Quarry Survey in the Aswan Region, Egypt: Shedding New Light on Ancient Quarrying." In Quarry Scapes: Ancient Stone Quarry Landscapes in the Eastern Mediterranean, ed. Nizar Abu-Jaber, Elizabeth G. Bloxam, Patrick Degryse, and Tom Heldal, 87-98. Geological Survey of Norway Special Publication I2. Trondheim, Norway: Geological Survey of Norway.

Kerley, Janet M. I989. "Preliminary Report on a Technological Analysis of Obsidian Artifacts from an Early Postclassic Workshop in Tula, Hidalgo.” In La obsidiana en Mesoamerica, ed. Margarita Gaxiola Gonzalez and John E. Clark, I65-I74. Mexico City: Instituto Nacional de Antropología e Historia.

Kenmotsu, Nancy. 1990. "Gunflints: A Study." Historical Archaeology 24 (2): 92-I24. Kent, Barry C. I983. "More on Gunflints.” Historical Archaeology I7 (2): 27-40. 
King, Eleanor M. 2000. "The Organization of Late Classic Lithic Production at the Prehistoric Maya Site of Colha, Belize: A Study in Complexity and Heterarchy.” $\mathrm{PhD}$ dissertation, University of Pennsylvania, Philadelphia.

Levine, Marc N., and David M. Carballo, eds. 2014. Obsidian Reflections: Symbolic Dimensions of Obsidian in Mesoamerica. Boulder: University Press of Colorado.

Lewis, Brandon S. I995. "The Role of Specialized Production in the Development of Socioeconomic Complexity: A Test Case from the Late Classic Maya." PhD dissertation, University of California, Los Angeles.

Lollet, Helene, Anne Hauzeur, and Jacek Lech. 2008. "The Prehistoric Flint Mining Complex at Spiennes (Belgium) on the Occasion of Its Discovery I40 Years Ago.” In Flint Mining in Prehistoric Europe: Interpreting the Archaeological Records, ed. Pierre Allard, Francoise Bostyn, Francois Gillghy, and Jacek Lech, 4I-77. BAR International Series I891. Oxford: Archaeopress.

Marx, Karl. I97i [1859]. Capital: A Critique of Political Economy. Moscow: Progress Publishers.

Maler, Teobert. 1902. Researches in the Central Portion of the Usumatsinta Valley: Report of the Explorations for the Museum I898-I90o. Memoirs of the Peabody Museum of American Archaeology and Ethnology, vol. r2 (I). Cambridge: Harvard University.

McCall, Grant S. 2012. "Ethnoarchaeology and the Organization of Lithic Technology." Journal of Archaeological Research 20: 157-203.

McCall, Grant S., and Rachel A. Horowitz. 2014. "Comparing Forager and Pastoralist Technological Organization in the Central Namib Desert, Western Namibia.” In Works in Stone: Contemporary Perspectives on Lithic Analysis, ed. Michael J. Shott, 63-77. Salt Lake City: University of Utah Press.

McCallum, Myles. 2009. "The Supply of Stone to the City of Rome: A Case Study of the Transport of Ancient Building Stone and Millstone from the Santa Trinita Quarry (Orvieto)." In Trade and Exchange: Archaeological Studies from History and Prebistory, ed. Carolyn D. Dillian and Carolyn L. White, 75-94. New York: Springer.

McDonald, Mary M.A. I99I. "Technological Organization and Sedentism in the Epipaleolithic of Dakhleh Oasis, Egypt." African Archaeological Review 9: 8I-Iog.

McNerney, Michael J. 1987. "Crab Orchard Core Technology at the Consol Site, Jackson County, Illinois." In The Organization of Core Technology, ed. Jay K. Johnson and Carol A. Morrow, 63-85. Boulder: Westview.

Milevski, Ianir. 2013. "The Exchange of Flint Tools in the Southern Levant during the Early Bronze Age." Lithic Technology 38 (3): 202-219.

Minc, Leah D. 2006. "Monitoring Regional Market Systems in Prehistory: Models, Methods, and Metrics." Journal of Anthropological Archaeology 25 (I): 82-II6.

Minc, Leah D. 2009. "Style and Substance: Evidence for Regionalism within the Aztec Market System.” Latin American Antiquity 20 (2): 343-374. 
Nelson, Margaret C. I99I. “The Study of Technological Organization.” In Archaeological Method and Theory, vol. 3, ed. Michael B. Schiffer, 57-10o. Tucson: University of Arizona Press.

Nishiaki, Yoshihiro. 200o. Lithic Technology of Neolithic Syria. BAR International Series 840. Oxford: Archaeopress.

Odell, George H. 200r. "The Use of Metal at a Wichita Contact Settlement." Southeastern Archaeology 20 (2): I73-I86.

Odell, George H. 2003. "Wichita Tools on First Contact with the French." In Stone Tool Traditions in the Contact Era, ed. Charles Cobb, 29-50. Tuscaloosa: University of Alabama Press.

Ogburn, Dennis E. 20Ir. "Obsidian in Southern Ecuador: The Carboncillo Source.” Latin American Antiquity 22 (I): 97-I20.

Ogburn, Dennis E. 20I3. "Variation in Inca Building Stone Quarry Operations in Peru and Ecuador." In Mining and Quarrying in the Ancient Andes: Sociopolitical, Economic, and Symbolic Dimensions, ed. Nicholas Tripcevich and Kevin J. Vaughn, 45-64. New York: Springer.

Parry, William J. 2002. "Aztec Blade Production Strategies in the Eastern Basin of Mexico." In Pathways to Prismatic Blades: A Study in Mesoamerican Obsidian Core Blade Technology, ed. Kenneth Hirth and Bradford Andrews, 36-45. Los Angeles: Cotsen Institute of Archaeology, University of California.

Parry, William J., and Robert L. Kelly. I987. "Expedient Core Technology and Sedentism." In The Organization of Core Technology, ed. Jay K. Johnson and Carol A. Morrow, 285-304. Boulder: Westview.

Peacock, David, and Valerie Maxfield. 2007. The Roman Imperial Quarries: Survey and Excavation at Mons Porphyrites 1994-1998, vol. 2: The Excavations. London: Egypt Exploration Society.

Quintero, Leslie A. 1996. "Flint Mining in the Pre-Pottery Neolithic: Preliminary Report on the Exploitation of Flint at Neolithic 'Ain Ghazal in Highland Jordan." In Neolithic Chipped Stone Industries of the Fertile Crescent, and Their Contemporaries in Adjacent Regions: Proceedings of the Second Workshop on PPN Chipped Lithic Industries, ed. Stefan Karol Kozlowski and Hans Georg K. Gebel, 233-242. Studies in Early Near Eastern Production, Subsistence, and Environment 3. Berlin: Ex Oriente.

Quintero, Leslie A., and Philip J. Wilke. 1995. "Evolution and Economic Significance of Naviform Core Blade Technology in the Southern Levant.” Paleoriente 2I (I): I7-33.

Raczek, Teresa P. 20Io. "In the Context of Copper: Indian Lithics in the 3rd Millennium BC.” In Lithic Technology in Metal Using Societies-Proceedings of a UISPP Workshop, Lisbon, September 2006, ed. Bert Valentin Eriksen, 23I-245. Hojbjerg, Denmark: Jutland Archaeological Society. 
Rosen, Steven A. 1983. "The Canaanean Blade and the Early Bronze Age.” Israel Exploration Journal 33 (I-2): 15-29.

Rosen, Steven A. 1996. "The Decline and Fall of Flint." In Stone Tools: Theoretical Insights into Human Prehistory, ed. George H. Odell, I39-158. New York: Plenum.

Rosen, Steven A. 1997. Lithics after the Stone Age: A Handbook of Stone Tools from the Levant. Walnut Creek, CA: Altamira.

Rosen, Steven A. 20Io. "The Desert and the Sown: A Lithic Perspective." In Lithic Technology in Metal Using Societies - Proceedings of a UISPP Workshop, Lisbon, September 2006, ed. Bert Valentin Eriksen, 203-2I9. Hojbjerg, Denmark: Jutland Archaeological Society.

Rosen, Steven A. 20I3. "Arrowheads, Axes, Ad Hoc, and Sickles: An Introduction to Aspects of Lithic Variability across the Near East in the Bronze and Iron Ages." Lithic Technology 38 (3): I4I-I49.

Rosen, Steven A, Aaron Shugar, and Jacob Vardi. 20I4. "Function and Value in Sickle Segment Analysis: Odellian Perspectives." In Works in Stone: Contemporary Perspectives on Lithic Analysis, ed. Michael J. Shott, Ir6-130. Salt Lake City: University of Utah Press.

Rule, Pamela, and Jane Evans. 1985. "The Relation of Morphological Variability to Hafting Technology among Paleoindian Endscrapers at the Shawnee Minisink Site.” In Shawnee Minisink: A Stratigraphic Paleoindian-Archaic Site in the Upper Delaware Valley of Pennsylvania, ed. Charles W.McNett Jr., 22I-259. Orlando: Academic.

Salazar, Diego, Cesar Borie, and Camilia Onate. 20I3. "Mining, Commensal Politics, and Ritual under Inca Rule in Atacama, North Chile." In Mining and Quarrying in the Ancient Andes: Sociopolitical, Economic, and Symbolic Dimensions, ed. Nicholas Tripcevich and Kevin J. Vaughn, 253-274. New York: Springer.

Santone, Leonore. I993. "Interregional Exchange: Aspects of the Prehistoric Lithic Economy of Northern Belize.” PhD dissertation, University of Texas, Austin. Schroeder, Ralph. 2005. "Introduction: The IEMP Model and Its Critics." In An Anatomy of Power: The Social Theory of Michael Mann, ed. John A. Hall and Ralph Schroeder, I-I6. Cambridge: Cambridge University Press.

Shott, Michael J. I989. "Technological Organization in Great Lakes Paleoindian Assemblages." In Eastern Paleoindian Lithic Resource Use, ed. Christopher J. Ellis and Jonathan C. Lothrop, 22I-237. Boulder: Westview.

Shott, Michael J. 1996. "Innovation and Selection in Prehistory: A Case Study from the American Bottom." In Stone Tools: Theoretical Insights into Human Prehistory, ed. George H. Odell, 279-3I4. New York: Plenum.

Shott, Michael J., and Kathryn J. Weedman. 2007. "Measuring Reduction in Stone Tools: An Ethnoarchaeological Study of Gamo Hidescrapers from Ethiopia." Journal of Archaeological Science 24: 1016-1035. 
Sorensen, Lasse. 20I0. "Obsidian from the Final Neolithic Site of Pangali in Western Greece: Development of Exchange Patterns in the Aegean.” In Lithic Technology in Metal Using Societies-Proceedings of a UISPP Workshop, Lisbon, September 2006, ed. Bert Valentin Eriksen, I83-202. Hojbjerg, Denmark: Jutland Archaeological Society.

Speal, C. Scott. 2009. "The Economic Geography of Chert Lithic Production in the Southern Maya Lowlands: A Comparative Examination of Early-Stage Reduction Debris." Latin American Antiquity 20 (I): 9I-II9.

Stark, Barbara L., and Christopher P. Garraty. 2oro. "Detecting Marketplace Exchange in Archaeology: A Methodological Review." In Archaeological Approaches to Market Exchange in Ancient Societies, ed. Christopher P. Garraty and Barbara L. Stark, 33-58. Boulder: University Press of Colorado.

Storemyr, Per, Elizabeth Bloxam, Tom Heldal, and Adel Kelany. 2oro. "Conservation of Ancient Stone Quarry Landscapes in Egypt." In Ancient Mines and Quarries: A Trans-Atlantic Perspective, ed. Margaret Brewer-LaPorta, Adrian Burke, and David Field, 38-55. Oxford: Oxbow Books.

Teather, Anne. 2orI. "Interpreting Hidden Chalk Art in Southern British Neolithic Flint Mines.” World Archaeology 43 (2): 230-25I.

Teltser, Patrice A. r99. "Generalized Core Technology and Tool Use: A Mississippian Example.” Journal of Field Archaeology I8 (3):363-375.

Tolmie, Clare. 20I3. "The Chatelperronian: Hybridity Culture or Indigenous Innovation?" In The Archaeology of Hybrid Material Culture, ed. Jeb J. Card, 279-294. Center for Archaeological Investigation, Occasional Paper 39. Carbondale: Southern Illinois University.

Torrence, Robin. 1984. "Monopoly or Direct Access? Industrial Organization at the Melos Obsidian Quarries." In Prehistoric Quarries and Lithic Production, ed. Jonathan E. Ericson and Barbara A. Purdy, 49-64. Cambridge: Cambridge University Press.

Torrence, Robin. 1986. Production and Exchange of Stone Tools: Prehistoric Obsidian in the Aegean. Cambridge: Cambridge University Press.

Tozzer, Alfred M. 1907. A Comparative Study of the Mayas and the Lacandones. New York: Archaeological Institute of America.

Tripcevich, Nicholas, and Daniel A. Contreras. 20Ir. "Quarrying Evidence at the Quispisisa Obsidian Source, Ayacucho, Peru.” Latin American Antiquity 22 (I); I2I-I36.

Tripcevich, Nicholas, and Daniel A. Contreras. 2013. "Archaeological Approaches to Obsidian Quarries: Investigations at the Quispisisa Source.” In Mining and Quarrying in the Ancient Andes: Sociopolitical, Economic, and Symbolic Dimensions, ed. Nicholas Tripcevich and Kevin J. Vaughn, 23-44. New York: Springer. 
van Gijn, Annelou. 20ro. "Not at All Obsolete: The Use of Flint in the Bronze Age Netherlands." In Lithic Technology in Metal Using Societies-Proceedings of a UISPP Workshop, Lisbon, September 20o6, ed. Bert Valentin Eriksen, 45-6o. Hojbjerg, Denmark: Jutland Archaeological Society.

Vaughn, Kevin J., Hendrick van Gijseghem, Verity H. Whalen, Jelmer Eerkens, and Moises Linares Grados. 20I3. "The Organization of Mining in Nasca during the Early Intermediate Period: Recent Evidence from Mina Primavera.” In Mining and Quarrying in the Ancient Andes: Sociopolitical, Economic, and Symbolic Dimensions, ed. Nicholas Tripcevich and Kevin J. Vaughn, I57-I82. New York: Springer.

Watt, David J., and Rachel A. Horowitz. 2017. "Analysis of a Gunflint Assemblage from the Natchez Fort Site (I6CTI8)." Southeastern Archaeology 36 (3): 214-225

Weedman, Kathryn J. 2000. "An Ethnoarchaeological Study of Stone Scrapers among the Gamo People of Southern Ethiopia." PhD dissertation, University of Florida, Gainesville.

Weedman, Kathryn J. 2002. "On the Spur of the Moment: Effects of Age and Experience on Hafted Stone Scraper Morphology.” American Antiquity 67: 73I-744.

Weedman, Kathryn J. 2006. "An Ethnoarchaeological Study of Hafting and Stone Tool Diversity among the Gamo of Ethiopia." Journal of Archaeological Method and Theory I3: 188-237.

Weigand, Phil C. 1989. "Notes Concerning the Use and Re-Use of Lithic Material among the Huicholes of Jalisco." In La obsidiana en Mesoamerica, ed. Margarita Gaxiola Gonzalez and John E. Clark, 465-466. Mexico City: Instituto Nacional de Antropología e Historia.

Weisberber, Gerd 1983. "The Technological Relationship between Flint Mining and Early Copper Mining." In The Human Uses of Flint and Chert: Proceedings of the Fourth International Flint Symposium Held at Brighton Polytechnic IO-I5 April, ed. G. de G. Sieveking and Mark H. Newcomer, I3I-I35. Cambridge: Cambridge University Press.

White, Stephen W. 1975. "On the Origins of Gunspalls.” Historical Archaeology 9: $65-73$.

Whittaker, John C. I996. "Athkiajas: A Cypriot Flintknapper and the Threshing Sledge Industry." Lithic Technology 2I (2): I08-I20.

Whittaker, John C. 20or. "The Oldest British Industry: Continuity and Obsolescence in a Flintknapper's Set Sample." Antiquity 75: 382-390.

Whittaker, John C. 2003. "Threshing Sledges and Threshing Floors in Cyprus." In Le Traitement des recoltes, un regard sur la diversite, du nelithique au present: XXIIII Rencontres Intrenationales D'Archéologie et D'historie D'antibes, ed. Patricia C. Anderson, Linda S. Cummings, and Thomas K. Schippers, 375-387. Antibes, France: Editions APDCA. 
Whittaker, John C. 2014a. "Threshing Processes and Tools: Exploring Diversity in the Past: An Introduction." In Explaining and Exploring Diversity in Agricultural Technology, ed. Annelou van Gijn, John C. Whittaker, and Patricia C. Anderson, I33-I35. Oxford: Oxbow Books.

Whittaker, John C. 20I4b. “Threshing Floors in Cyprus.” In Explaining and Exploring Diversity in Agricultural Technology, ed. Annelou van Gijn, John C. Whittaker, and Patricia C. Anderson, I36-I37. Oxford: Oxbow Books.

Whittaker, John C. 20I4c. "The Manufacture and Use of Threshing Sledges." In Explaining and Exploring Diversity in Agricultural Technology, ed. Annelou van Gijn, John C. Whittaker, and Patricia C. Anderson, I4I-I44. Oxford: Oxbow Books.

Whittaker, John C., Kathryn Kamp, and Emek Yilmaz. 20o9. "Cakmak Revisited: Turkish Flintknappers Today.” Lithic Technology 34: 92-IIo.

Wilke, Philip J. 1996. "Bullet-Shaped Microblade Cores of the Near Eastern Neolithic: Experimental Replicative Studies.” In Neolithic Chipped Stone Industries of the Fertile Crescent and Their Contemporaries in Adjacent Regions: Proceedings of the Second Workshop on PPN Chipped Lithic Industries, ed. Stefan Karol Kozlowski and Hans Georg K. Gebel, 289-310. Studies in Early Near Eastern Production, Subsistence, and Environment 3. Berlin: Ex Oriente.

Wilke, Philip J., and Leslie A. Quintero. I994. "Naviform Core and Blade Technology: Assemblage Character as Determined by Replicative Experiments." In Neolithic Chipped Stone Industries of the Fertile Crescent. Proceedings of the first workshop on PPN Chipped Lithic Industries, ed. Hans Georg K. Gebel and Stefan Karol Kozlowski, 33-60. Studies in Early Near Eastern Production, Subsistence, and Environment r. Berlin: Ex Oriente.

Woodall, J. Ned, Stephen T. Trage, and Roger W. Kirchen. 1997. "Gunflint Production in the Monti Lessini, Italy." Historical Archaeology 3I (4): 15-27.

Yerkes, Richard W. 200o. "Ethnoarchaeology in Central Cyprus: Interdisciplinary Studies of Ancient Population and Agriculture by the Athienou Archaeological Project." Near Eastern Archaeology 63 (I): 20-34. 